\title{
УПЕРШЕ ВСЕСВІТНЬОВІДОМА ПЕРЕКЛАДОЗНАВЧА ЕНЦИКЛОПЕДІЯ - УКРАЇНСЬКОЮ МОВОЮ
}

\author{
Рецензія
}

на «Енциклопедію перекладознавства: у 4-х томах. Т. 1: пер. $з$ англ. / за ред. Іва Гамб’є та Люка ван Дорслара; за заг. ред.: О. А. Кальниченка та Л. М. Черноватого - Вінниця: Нова книга, 2020. - 551 с. (Cepiя UTTU Series)»

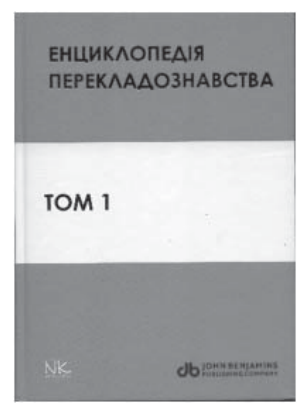

Закордонна перекладознавча література майже не перекладається в нашій країні, за винятком деяких статей в університетських виданнях, тим більше, коли йдеться про такі зазвичай великі за обсягом книги, як енциклопедії. Водночас наукові енциклопедії високого рівня як світові надбання заслуговують на переклад і таки перекладаються. Вони призначені бути справжніми скарбницями спеціальних знань та звичайно характеризуються великою достовірністю, перевіреністю фактів, фундаментальністю i, одночасно, здатністю викликати плідну дискусію. Саме через це їх слід перекладати, аби сприяти науковому розвитку в країні перекладу.

Тому варто вітати факт видання перекладу українською мовою першого тому такого авторитетного у світі, як Handbook of Translation Studies, тим більше що в Україні були відсутні будь-які серйозні довідкові видання 3 перекладознавства. Цей переклад вийшов у світ у серії під егідою та завдяки сприянню Всеукраїнської спілки викладачів перекладу як уже десяте видання.

Потрібно окремо наголосити на значній складності цього перекладацького проєкту, оскільки, по-перше, раніше подібні масштабні проєкти в нашій країні не здійснювалися, по-друге, перекладознавча термінологія англійською мовою розвинена значно більше, ніж українською, тому природно, що немало українських відповідників англійських термінів, особливо відносно нових, відсутні, та, по-третє, українська перекладознавча термінологія досі ще недостатньо уніфікована і стандартизована в тому числі й у зв'язку з відсутністю тлумачних або перекладних термінологічних словників.

На теперішній час у світі зроблено 344 переклади статей цієї чотиритомної енциклопедії, представлених в онлайні тринадцятьма мовами [1] . Найбільше перекладів статей виконано українською мовою (120 статей (тобто перекладено увесь перший том видання та частину статей з інших томів), і значно менше - 88 статей - французькою мовою, тому можна стверджувати, що українські перекладознавці встановили своєрідний рекорд 3 перекладу цієї енциклопедії.

Видання перекладознавчої енциклопедії, хоч і в перекладі, становить важливу віху в закріпленні в країні статусу науки, у нашому випадку - перекладознавства. Таке видання стимулює перекладознавців до подальшого розвитку, привертає увагу наукової молоді, сприяє уніфікації та стандартизації перекладознавчої термінології, активізує написання та публікацію наукових статей, посібників, підручників та довідників і заохочує вищі заклади освіти, де викладаєть та досліджують переклад, до проведення наукових дискусій та конференцій. До речі, галузеві енциклопедії та довідники - це саме ті видання, які повинні мати у своїй бібліотеці професіонали з певної галузі.

3-посеред авторів рецензованого першого тому такі відомі у світі дослідники перекладу, як Ампаро Уртадо Альбір, Фабіу Альвес, Мері Снел-Горнбі, Ів Гамб'є, Даніель Гуадек, Люк ван Дорслар, Дороті Келлі, Сара Лавіоза, Маріанн Ледерер, Кірстен Малмк'єр, Джеремі Мандей, Крістіана Норд, Мев Ологан, Алешандра Асіш Роза, Луїз фон Флотов, Дебора Цао, Крістіна Шефнер та інші.

У 74 статтях енциклопедії представлено найважливіші грані перекладознавства - ключові елементи його концептуального та термінологічного апарату («переклад», «адаптація», «автопереклад», «перекладознавство», «трансфер» тощо), розділи та підрозділи перекладознавства (історія перекладу, машинний переклад, прикладне перекладознавство та ін.), теорії та моделі перекладу (усного, аудіовізуального, письмового тощо), підходи до дослідження перекладу (дескриптивний, прикладний, інтерпретативний, когнітивний, етнографічний, функціональний та ін.); аспекти перекладу (релевантність, норми, одиниці, стратегії, множинність, відкритість і закритість тощо), зв'язки перекладу з іншими, переважносуміжними, науками (зокрема такими, як літературознавство, семіотика, термінознавство, герменевтика, етика, журналістика, соціологія тощо), методи перекладознавчого дослідження (корпусні, експериментальні та ін.), особливості перекладу текстів різних жанрів, типи та види перекладу (письмовий та усний переклад, комп'ютерний переклад, галузевий переклад тощо), питання застосування інформаційних технологій у перекладі; нетворкінг та діяльність перекладачів-волонтерів; зміст і структура процесу перекладу та інструменти його дослідження, якість перекладу і класифікація перекладацьких помилок, проблеми методики навчання перекладу тощо.

Загалом рецензоване видання характеризується високою інформаційною насиченістю, відповідністю потребам поширення знань про переклад та перекладознавство і розвитку науки про переклад узагалі. Обсяг публікації доволі великий - 45,67 ум. друк. арк., її поліграфічна якість на достатньому рівні: тверда палітурка з чітким дизайном, офсетний папір та офсетний друк. Перекладена енциклопедія частково компенсує певний брак якісної довідкової українськомовної літератури з перекладознавства (у таких ситуаціях лакуни в національній науковій літературі зазвичай заповнюються перекладною літературою) та забезпечує доступ студентів, аспірантів і викладачів перекладу (які за межами провідних перекладознавчих центрів не мають достатньо глибоких знань 3 перекладознавства) до доволі систематизованого джерела західних теорій, поглядів та наукових тлумачень. Вона дозволяє критично аналізувати висловлені міркування перекладознавців як у межах лекцій і семінарів, так i 
в наукових публікаціях і формувати власні підходи до розв'язання відповідних проблем; вона дає змогу розпочати обговорення проблем української перекладознавчої термінології, які чітко виявляються в перекладах різних статей енциклопедії і має підштовхнути українських перекладознавців до створення власної довідкової літератури, яка б ураховувала і світовий, і національний досвід.

Щодо перекладу першого тому енциклопедії є кілька побажань, які мають на меті поліпшення якості в разі перекладу наступних томів енциклопедії та можливого перевидання першого тому. Як нам видається, зовсім не зайвими були б в українському виданні енциклопедії предметний та іменний покажчики, що суттєво б допомогло читачеві орієнтуватися в обсяжному (довідковому!) томі та швидко знаходити потрібну інформацію.

У бібліографічному описі анотації книги на сторінці вихідних даних ім'я та прізвище одного зі співредакторів книги помилково зазначені як Івз Гамбіер (в оригіналі Yves Gambier), тоді як у статті на 310 сторінці та в самій анотації довідника дано правильне транскодування - Ів Гамб'є.

У назвах деяких статтях наявні два варіанти перекладу терміна, що неприпустимо в друкованому виданні, де переклад повинен подаватися без варіантів. Наприклад, у перекладі назви статті "Descriptive Translation Studies" $є$ другий варіант перекладу терміна descriptive - “Дескриптивне (описове) перекладознавство” (с. 77), хоча термін “дескриптивний” в українській мові вже доволі усталений. У перекладі назви статті “Transfer and Transfer Studies” (c. 332) як "Перенос (трансфер) та трансферні студії” також наведено другий варіант перекладу першого у назві терміна, хоча зазначений етап процесу перекладу звичайно позначається в українській мові терміном “трансфер”. Переклад назви статті “Community Interpreting” також подано з двома варіантами перекладу слова "community" - "Усний переклад для потреб громади / Усний переклад у соціальній сфері” (с. 503). Тут перекладачу слід було б зупинитися на останньому варіанті як наразі вже значно частотнішому. Зайвим у перекладі назви статті “Consecutive Interpreting” видається наявність слова “усний” - "Послідовний усний переклад” (с. 363), оскільки наявність терміну “послідовний” уже передбачає, що йдеться про усний переклад.

Термін "technical translation" у назві статті неправильно перекладений як “технічний переклад” (с. 486) - потрібно “Спеціалізований / спеціальний переклад”, це типова помилка ще з тих часів, коли термін "technical aid" став перекладатися як “технічна допомога” (правильно “спеціальна / спеціалізована допомога" (консультаціями тощо), адже сам перекладач уживає в перекладі статті термін “моделі спеціалізованої комунікації” (с. 486).

На с. 200 англійський термін у множині corpora перекладено українським відповідником в однині “корпус" (правильніше було б “корпуси текстів”). Термін computeraided translation слід, на наш погляд, перекладати не як “автоматизований переклад” (с. 10, 163, 215 та ін.), а “переклад за допомогою (комп’ютерних) апаратно-програмних засобів".

Помилковим $є$ транскодування деяких власних імен авторів статей, наприклад на с. 127 ірландське ім'я Siobhan слід передавати українською як Шивон, а не як Сьобган, на c. 17 ім'я Chiara помилково подано з м'яким знаком (Кьяра) замість правильного написання українською мовою К'яра, а на с. 343 у прізвищі одного із співавторів статті не надрукована остання літера - замість Коскінен подано Коскіне, а ім'я другого співавтора транскодоване неправильно як Оуті, а не як потрібно - Уті. На с. 392 ім'я та прізвище автора статті подано неправильно - Рітта Яааскелайнен замість Рійтта Яаскеляйнен, на с. 403 ім'я та прізвище одного вченого подано разом - ФабіуАлвес (до речі, на с. 153 бачимо вже Фабіо Альвес), і таке ж написання разом зустрічається на с. 332 у зазначенні перекладача статті - AndriiKozachuk.

У перекладах спостерігається інтерфероване (з російської мови) вживання прийменника “при” у сполученні 3 наступним іменником на кшталт "При вивченні політичного перекладу...” (с. 357) та “...що може відбуватися при перекладі...” (с. 196). В українському мовленні в таких випадках уживаються прийменники “для”, “під час” та “у разі” або дієприслівниковий зворот: У разі вивчення..., Вивчаючи...; “...що може відбуватися під час ...” .

Слід було б навести пояснення значення рідковживаного терміна “канібалістський переклад”, вжитого на c. 357 (в англійській мові - “cannibalistic translation" - це переклад, який пориває зв’язок з оригіналом та стає нібито головним текстом унаслідок дій “деміурга”-перекладача) [2].

У деяких випадках у перекладі (наприклад, на с. 198) спостерігається типова інтерференційна помилка в перекладі англійського прикметника linguistic у сполученні 3 іменниками (у цьому разі 3 “data”), який має два значення -"related to language" та "related to linguistics", але в першому значенні повинний перекладатися (стосовно мовних елементів тощо) не як “лінгвістичні дані”, а як “мовні дані”, а у другому значенні - як “лінгвістичний” (наприклад, вісник або університет).

Попри викладені вище зауваження, рецензований перший том "Енциклопедії перекладознавства” у перекладі українською мовою є актуальною, дуже корисною та потрібною працею, яка, безперечно, прислужиться справі розвитку науки про переклад в Україні. Із нетерпінням можна очікувати появи перекладів інших трьох томів цього популярного видання, а редакторам та усім перекладознавцям слід побажати подальшого плідного співробітництва зі світовими центрами видання перекладознавчої літератури.

\section{ЛITEPATYPA}

1. Statistics. URL.: https://benjamins.com/online/hts/list/statistics (дата звернення 26.09.21).

2. Guldin R. Devouring the Other: cannibalism, translation and the construction of cultural identity // URL.: https://www.academia. edu/2111494/Devouring_the_Other_cannibalism_translation_ and_the_construction_of_cultural_identity) (дата звернення 30.09.21).

Професор кафедри теорії та практики перекладу з англійської мови Інституту філології Київського національного університету імені Тараса Шевченка, доктор філологічних наук професор Карабан В.І.

Отримано 05.10.20 